\title{
FLEXIBLE FORMS OF WORK AND WORK ENGAGEMENT
}

\begin{abstract}
Global trends in the working world clearly show the changes in the character of labor relations with a significant representation of flexible forms of work. It is an atypical form of work organization that arises as a consequence of strong globalization flows, economic crisis, information and technological revolution, and which stands against the labor law standard of a classical employment, being represented in the form of the employment contract for an indefinite period of time with full time employment. Starting from the concept of flexicurity as the dominant concept in the EU, flexicurity seeks to establish a balance between flexibility in the organization of work in order to preserve stability. Through the flexible organization of work and working hours, there establishes a kind of balance between working hours, the rest time and time for socialization and social activity. However, on the other hand, a flexible organization of work can reduce the rights of the employees and workers outside the employment relationship, especially if this form of work is abused in practice by the contracts concluded contrary to their essence or legal norm. The authors use the historical, comparative- legal and sociological method, as well as the statistical data in the analysis of research subjects with the aim of providing the concrete proposals for the improvement of the existing normative framework.
\end{abstract}

\footnotetext{
* LLD, assistant teacher and associate, The University of Business Academy in Novi Sad, The Faculty of Law for Commerce and Judiciary in Novi Sad, A consultant at Laura consulting ltd, e-mail: g.sladja@yahoo.com

${ }^{* *}$ LLD, Associate Professor, The University of Business Academy in Novi Sad, The Faculty of Law for Commerce and Judiciary in Novi Sad, e-mail: sanja@pravni-fakultet.info

(c) () (C) 2021 by the authors. This article is an open access article distributed under the terms and conditions of the Creative Commons Attribution (CC BY) license (https://creativecommons. org/licenses/by/4.0/).
} 
Keywords: work and labor relations, flexible forms of work, flexible organization of working hours.

\section{Introduction}

In accordance with the social and economic changes in the world, there are changes in the world of work as well. The flexibility of work is most often considered a consequence of globalization, which represents the general connection and movement of people, goods, services, and information in the world, through the multiple connections of states and societies. Due to globalization, the social context of business is changing, there is a transformation of work and management, but also a change in the role of the state through reduced interventionism and finally, deregulation of labor regulations (Jašarević, 2012, pp. 175-176). Labor law suddenly becomes too rigid for new circumstances, and new relations between employers and employees, which leads to a reduction in workers' rights and a worsening of their position (Jašarević, 2018, p. 926).

Flexible forms of work, therefore, become inevitable given the changes in the nature of labor relations, but also strong globalization flows that lead to the abandonment of the labor law standard, in the form of a classic employment relationship (indefinite contract, full-time work), paving the way for flexible forms of work that are manifested both during employment (fixedterm contract, part-time work), and through new forms of work outside employment (contract on temporary and occasional jobs, contract on additional work), as well as through new forms of work (telework), (work at home), with new forms of platform work and work through ICT technology (Škorić, 2020, p. 1). Recently, the European Commission defined telecommuting as "employees or contractors working from home (instead of traveling to the employer's or client's premises) using information and communication technology. Teleworking is also seen as an enhanced environmental initiative to reduce suburban traffic and pollution emissions. Teleworking is also promoted to increase job satisfaction (through reduced stress and travel time) (Van Eyck, 2003, p. 19).

Flexibility in the field of employment is becoming an integral part of the organization of work and production as companies strive to reduce costs and provide competitiveness in times of rapid changes in the market and in technologies (Van Eyck, 2003. p. 1). Employers often face the reality that in order to maintain their business, they have to reduce costs, especially employee costs. Flexibility has offered new opportunities for small businesses to 
connect with large companies, but it has also reduced the economic and social security of workers and increased their vulnerability to exploitation (such as discrimination, harassment, etc.), especially in situation where the labor market is insufficiently regulated (Van Eyck, 2003. p. 1).

Therefore, the functioning and regulation of labor relations is experiencing serious changes, which is visible especially in the idea that the stability of labor relations is completely rejected, as outdated, from the best intentions, to preserve employment (Midžović, 2020, p. 352). Such ideas are advocated also by the World Bank and the International Monetary Fund, the great spokespersons of neoliberalism. On the other hand, as Midžović rightly points out that with the disruption of employment stability, employees face the loss of legal and other protection, their standard of living is reduced, dignity is violated, health and safety at work is weak, social insurance of workers and their families is undermined and much more indirectly derives from employment status (Midžović, 2020, p. 352). Although flexible forms of work are increasingly used in practice, legally speaking, they are not sufficiently regulated. Many people who work in an atypical form of work, work illegally, have no protection, and on the other hand, by such actions of employers, the state is at a loss, since it does not collect taxes and contributions based on wages or monetary compensation. Such persons should be provided with social security, with at least a minimum of employment law, to provide them with decent working conditions for the sake of living a dignified life. ${ }^{1}$

\section{Employment and non-employment in the light of work flexibility}

Employment is a relationship that is established between unequal parties, the employer, and the employee, between whom there is a relationship of legal subordination, it is a bilateral employment relationship that involves personal performance of work by the employee, while the risk of job security

${ }^{1}$ This is exactly what is achieved in Anglo-Saxon and European continental law, in work in atypical forms of work by prescribing and providing protection against psychosocial risks such as discrimination, harassment at work, whistleblowing and more recently by introducing the principle of gender equality, to enable equal gender representation when establishing and during employment status. In the same way, in the domestic legislation, starting from 2009, positive regulations on protection from harassment at work, discrimination and whistleblowing provide equal protection for employees and workers outside employment status, which contributes to the general well-being of those persons and preservation of dignity at work. All this represents the penetration of human rights and freedoms into labor law in a situation where neoliberalism dominates, which leads to deregulation and flexibility of labor law. 
carries by the employer and the employee invest his working ability, knowledge and skills in performing work tasks (on a daily, weekly, monthly level), and on the basis of which he realizes the right to salary, which the employer is obliged to pay. On the other hand, the flexibility of work implies the introduction of new forms of work, which abandons the idea of concluding an employment contract for an indefinite period with all the benefits it includes and implies, with the development of precarious or "unconventional work", with which we have less rights, worse working conditions, and uncertainty regarding the length of employment (Reljanović, 2020, p. 34). What is being implemented is a kind of flexibility of employment. It should be noted that in some countries, such as Malta (based on the Decision on National Employment Standards) and Portugal (Labor Law), it is prescribed that persons working outside employment status and legal subordination and performing jobs like those performed by employees at the employer will have the status equivalent to an employed person, which ensures labor rights, protection of health and safety, prohibition of discrimination (Jašarević, 2018, p. 933.)

Flexible forms of work, such as part-time or casual work, do not necessarily have to be associated with precarious work or insecure forms of work. In situations where labor law provides adequate social protection for flexible workers, a flexible form of work can serve as a bridge to long-term employment or a supplement to long productive activities (Van Eyck, 2003. p. 8). If we are at the level of employment outside employment status, what is unquestionably is that such workers need protection from health and safety at work, but also some social rights, such as the right to information and the right to consultation, as a solid core of social rights, in addition to social security and social protection rights. Providing a smaller scope of labor protection for workers in a flexible form of work is a challenge that labor legislation faces. ${ }^{2}$

\footnotetext{
${ }^{2}$ In our Labor Law (Articles 197-202) it is determined that work outside the employment relationship consists of the following contracts: service contract, contract on temporary and occasional jobs, contract on additional work and contract on professional training and specialization. Workers, based on these contracts, enjoy a smaller scope of rights than comparable employees engaged based on employment. They do not have the right to annual leave, they are not entitled to salary (they are entitled to financial compensation), the right to some other income arising from employment, which significantly complicates their position, making it more insecure, especially in terms of social status of these persons, since the taxes paid into disability pension funds based on cash benefits do not enter the years of mandatory pension insurance. In that way, taxes for all months or years of work outside of employment status are not included in the sum that is needed to meet one of the cumulative conditions for exercising the right to an old-age pension, which in our law is 15 years of compulsory social insurance. This is the disadvantage of work flexibility.
} 
The concept of flexibility is becoming the dominant concept in the European Union in the new millennium. This concept is based on four pillars: reliable and flexible contractual relations, lifelong learning, effective employment policy and a modern concept of social security, through social protection of unemployed persons, through the material security system while in that status, while enabling these persons with fast access to the labor market. Through the concept of flexicurity, the representation of contracts that do not establish employment becomes dominant.

There are the following forms of atypical forms of work in our legal system. Some represent work from employment and some work outside employment. These are: fixed-term contract, part-time contract, contract with domestic and support staff, contract for work outside the employer's premises, contract for agency employment (employment relationship) and service contract, contract for temporary and occasional jobs, contract for additional work, contract on professional training and advanced training, contract on volunteer work, contract on royalties, contract on seasonal work (work outside employment). Workers who are engaged in the regime outside the employment relationship have a significantly smaller scope of rights, which contributes to the more uncertain labor and social law status of such persons, which leads to a field of "secondary position in relation to employees" (Jašarević, 2012, p. 191).

It is necessary to point out that the main law for the field of labor in Serbia does not contain a definition of employment, which de lege ferenda needs to be changed since mutual rights, obligations and responsibilities of employees and employers arise from employment. Employment is the pillar and cornerstone of all labor law. The Labor Law precisely defines the term employee, but if we do not have a precisely defined employment relationship, then we are in a field where abuses are possible and very common. In fact, in that way, everyone who works for an employer and is not employed has no employment rights or protection (Jašarević, 2012, p. 191). Furthermore, it is necessary to specify and define the concept of work engagement, to be clear in what it differs from the employment relationship, and especially to specify the scope of rights and protection enjoyed by workers outside the employment relationship at the employer. In practice, it often happens that forms of atypical work are abused through contracts on temporary and occasional jobs or through false self-employment, persons who were previously employed by the employer, so they continue to be engaged, e.g., through temporary employment agencies. Inspections need to be strengthened in these cases. At the same time, a fixed-term employment contract is concluded for a certain period of time, due to the temporary and specific needs of the employer (Kovačević, 
2016 , p. 76) ${ }^{3}$, but in practice it is often abused, because it essentially conceals the constant and continuous need for employees, since it is easier for the employer to terminate this form of employment, with the expiration of the contract, if for some reason the employee no longer suits him.

It should be noted that flexibility is achieved not only by deregulation, through the reduction of rights and the number of employees, but also by flexible organization of work and working hours by applying innovative approaches (Jašarević, 2012, p. 178).

\section{The concept of work flexibility, forms, and types of work flexibility}

The concept of work flexibility is not legally defined, and its definition should be approached with caution, bearing in mind the two meanings it serves to denote new forms of work organization and special types of employment contracts (Kovačević, 2013, p. 121). The term "flexible work" means work that is adaptable and changeable in terms of conditions and the organization of work (working hours, organization of work tasks, flexibility in terms of wages, etc.). It is about adaptability to changes in the labor market, within flexibility in the field of labor and labor relations is manifested in various ways, so that the following types of flexibility in labor relations are mentioned: internal and external flexibility (outside and inside the company), functional, numerical, and financial flexibility, flexible (atypical) forms of work engagement, flexibility of working hours, flexible work organization (Jašarević, 2012, p. 179). A survey conducted by Trades Union Congress (TUC) shows that more than four out of five $(82 \%)$ workers in the UK want to work flexibly in the future, up to $87 \%$ among women's workers, which is the most significant fact indicating popularity flexible workload among workers (TUC, p. 3).

\footnotetext{
${ }^{3}$ In our law, the Labor Law, Article 37, para. 1 prescribes that a fixed-term employment contract may be concluded for the establishment of an employment relationship whose duration is determined in advance by objective reasons that are justified by the deadline or the execution of a certain job or the occurrence of a certain event during those needs. We have a similar approach to French law, but without real control in practice of the reasons for concluding these contracts. Although it is clear from the letter of the law that the issue is a specific project or execution of work (objective reason), often in practice this contract is used for jobs for which there is a constant and continuous need with the employer. Another problem relates to succession, because several of the same or similar fixedterm employment contracts are concluded with the same employee. In our law, the amendment to the Labor Law 2014, Art. 37. par. 2 enables explicit succession, i.e., the conclusion of one or more (unlimited number) fixed-term contracts with the same persons, provided that the time is limited to 24 months, with or without interruptions.
} 
Flexibility in employment, therefore, includes the possibility of adjusting employers and employees or workers outside employment to new working conditions, which is reflected in easier access to the labor market, faster labor movement and changes in nature of work engagement (fluctuation from employment to work outside employment and vice versa). Flexibility in employment is also characterized by the unequal relationship of the parties to the employment relationship, having in mind the legal subordination and the position of the employer as a stronger party. The notion of subordination, therefore, implies the relationship of two unequal subjects from which "one of them has less significance or narrower authority in relation to the other who is his superior and on whom he depends" (Kovačević, 2013, p. 20). Accordingly, the employer creates working and employment conditions, which employees or workers outside employment must adjust to by accepting, with a greater possibility of negotiation, if the employer has a trade union, and working conditions can be agreed by collective bargaining. If there is no union with the employer, flexibility will be reduced to the unilateral will of the employer, which unilaterally adopts general acts within the normative framework, while flexibility (adaptability) will be at a high level for the employee, because it adapts to the undoubted will of the employer, in terms of working conditions and organization.

Functional flexibility means changing the production system, technology, or work organization (more flexible work organization, which means that employees move more easily within the company; includes "job rotation", "job expansion"), additional types of work engagement (wider application of "flexible forms of work"), reduction of restrictions on employment and dismissal, allocation of production and labor (through subcontracting) to improve work efficiency (Jašarević, 2012, p. 180). Numerical flexibility means adjusting the number of workers to market demands, to harmonize labor costs with market needs, which leads to a larger number of employees outside the employment relationship and includes more flexible regulations in hiring and firing (Jašarević, 2012, p. 180). In this way, employers reduce labor costs since those hired outside the employment relationship are not entitled to severance pay upon termination of employment, the dismissal procedure is easier for them, both in terms of deadlines and legal basis (they can carry out mass dismissals without penalties), and finally, the scope of rights of this group of persons is smaller than employees who work in employment (the right to recourse, jubilee award, some additional benefits 
arising from employment, such as financial assistance in case of death of a close family member, etc.). ${ }^{4}$

Financial flexibility means earnings that are not included in a fixed amount but are prone to change depending on economic market trends. Therefore, if there are financial problems in the business of the company, in that case the salary can be reduced, but it should not be below the minimum wages (guarantor of dignity at work and ensuring the basic existence of the employee). This guarantee usually applies to employees, not to workers outside employment status, which needs to be prescribed through labor legislation.

The most common flexible forms of work from an employment relationship are fixed-term contracts work, part-time work, work from home. Statistics show that in OECD countries the participation of women in part-time work is higher than $60 \%$. While women tend to remain part-time employees in the Netherlands in the long run, in Sweden both men and women are more likely to switch from full-time to part-time and vice versa (Van Eyck, 2003, pp. 37-38). In the United States, employers have no obligation to provide part-time employees with proportional salaries and benefits for full-time employees, and the percentage of parttime employees is high (Van Eyck, 2003, p. 40). Work outside the employment relationship is work under a contract on occasional and temporary jobs, telework, domestic workers, self-employment, work on weekends etc (Urdarević, 2020, p. 75). We also add the temporary assignment of workers through employment agencies to the flexible form of work. New forms of work are a form of flexibility at work. By them, we primarily mean occasional work (work on call and contracts with zero working hours), work based on vouchers, employee sharing and job sharing, portfolio work, work through platforms and mobile work based on information and communication technologies (Kovačević, 2021, pp. 90-114).

\section{Flexible work and working hours}

The organization of working time includes measurable characteristics of work responsibilities in the company in terms of length and time, as well as the schedule (stable, i.e., fixed, or flexible) of the time in which work is

\footnotetext{
${ }^{4}$ Numerical flexibility is achieved by outsourcing employment contracts, where subcontractors continue to be part of production processes, but their employment relationship is no longer with the parent company. This is achieved by hiring workers through agency employment, where agencies appear as employment intermediaries. The employee concludes an employment contract with the agency and is referred to work with the employer, with whom the agency has a contractual relationship. This is a specific triple legal relationship between the employee, the agency, and the employer of the service user, where the performance of work is performed.
} 
performed or not performed, measured during a particular day, week, month or for a longer period, so that the criteria are applied to all jobs, including informal employment. (Working Time Resolution, 2008, p. 46). Flexible forms of work need to be observed through flexible organization of working hours, which is one component of this form of work. Flexible organization of working hours, namely, is one of the key elements of work organization and the possibility of establishing a balance between professional and private life of an employee or workers outside employment status. Flexible working hours is a period of time in which the employee is obliged to perform work tasks, conscientiously and responsibly, according to the order of the employer, and which does not take place according to a fixed schedule, and the employee can organize work activities at its discretion, taking into account that work orders be completed within the set deadlines. The most common flexible working hours are flexible working-time arrangements (characterized by possible daily and weekly working time scheduled outside usual, fixed schedule when presence at the place of employment is compulsory) and on-call work, zero hours or "as and when required" arrangements (characterized by no fixed schedule of contractual hours, but there is a requirement for persons to be available for work when they are called with prior notice, for as many working hours as the employer requires up to the legally determined maximum or contractually limited number of working hours) (Working Time Resolution, 2008, p. 55).

Modern globalization trends, neoliberalism and technological revolution have caused the development of new forms of work via the Internet and information and communication technologies (smartphones, personal computers, tablets), which leads to the imposition of flexibility in the organization of working time, as a kind of necessity. In this sense, the traditional model of organization of working time, which implies a stable, standardized, uniform and strict organization of (full) working time, becomes an obstacle to cost rationalization (Kovačević, 2008, p. 225) Therefore, flexibility in organizing working hours enables employers to increase productivity and competitiveness in the market because labor costs are reduced. This is the main reason to affirm flexible working hours, which implies greater diversification of working time arrangements, so that working hours can be organized as full or part time, as fixed or flexible working hours, as working hours calculated according to weekly working hours or annually, and the like (Kovačević, 2008, p. 225) The most common forms of flexible working hours are reflected in the flexible organization of working hours, a shortened working week (which lasts four or even three working days) conditionally free working time and teleworking. In addition to a part-time work, flexibility in organizing working hours is achieved during a compressed 
working week. Workers can opt for a shortened work week that includes 40 hours of work but is organized in four days (Monday to Thursday, Tuesday to Friday or until Wednesday to Saturday), so the working day lasts 10 hours with one extra day off per week. This way of organizing working hours may be relevant for companies that intend to expand the availability of their service or production (Van Eyck, 2003, p. 19). Teleworking through new information and communication technologies (ICT technologies) enables a permanent connection, producing on the other hand a blurred line between paid working time and time and space that are usually reserved for personal life (Messenger, 2018, p. 5). The shortcoming of this work organization can be seen in that.

Is technological progress a continuous work towards reducing working hours and the working week, which is the subject of constant debate in the Nordic countries? Is this possible in the world of work? This is possible but requires public policies that work to constantly promote the reduction of working hours, for workers who work too long, with a guarantee of minimum working hours for part-time workers with a small number of working hours, as well as for non-employed workers (Messenger, 2018. p. 5). Here it is important to point out that in the countries where most of the workforce is employed part-time, there exists a statistic which indicates that such workers tend to make a faster transition from work engagement to employment status; as well as move from lower-paid to higher-paid jobs, coupled with a shorter retention span and therefore faster turnover (Ostrovidov Jakšić, 2017, p. 50).

In our legal system, the decision on the schedule of working hours is made by the employer. The working week lasts 40 hours, it can be shortened to 36 hours, and in some situations to 30 hours, when we have an employee who works on jobs with increased risk. The work week can last a maximum of 48 hours, including 8 hours of overtime. This is a common legal norm in most normative systems of the countries of the world, which is in accordance with the international standard Convention No. 1 on Working Time from 1919. In our law for the field of work in Art. 55, para. 5 prescribes a provision on sliding working hours, which represents the application of the idea of work flexibility in practice. De lege ferenda, for the sake of legal certainty, it is necessary to specify the institute of sliding working hours.

\section{Conclusion}

Flexibility in the organization of labor is the response of employers and countries in the world, to the new conditions of the labor market and capital, as well as to the stage in the development of capitalism, neoliberal capitalism. 
States, employers, and workers view the problem of labor flexibility from different angles. Employers want to reduce labor costs to remain competitive in the domestic and international markets. On the other hand, employees want protectionist labor and social legislation, while state preferences reduce unemployment. Flexibility in employment and labor relations exists as a tacit consent of states and employers' organizations (large capital owners) and trade unions, on the other hand, as an effective way to maintain employment, by flexible working hours and labor organization, with active access to the labor market of unemployed persons. It is a constant political struggle of the three sides of the social dialogue who are looking for the advantages of flexibilization, having in mind the changes in the legislation, the organization of work and the distribution of income. But the only way to reconcile productivity, stability and flexibility is to preserve employment stability through employment, with the possibility that some elements of work organization, such as working time, remain flexible.

To have "fair flexibility", it is necessary for employers, employees, and the state to provide equal contribution, and if there is a transition of work engagement, to help the vulnerable person in quickly finding new jobs through national and private employment agencies. It takes the state to provide social security for these persons through the social security system while the social risk of unemployment lasts. At the same time, the full application of the principle of equality should be enabled by enabling employees working in atypical forms of work to have the same rights, working conditions and scope of protection as comparably employed persons, in proportion to the length of working hours. Also, new labor law solutions must provide protection for those workers outside employment status, guaranteeing them a minimum wage, protection of health and safety at work and rights from the social security system, (Van Eyck, 2003, p. 19) in addition to collective rights (information, consulting, trade union organization), but also the right to vocational training and development to remain competitive in the labor market.

In Serbia, the flexibility of work has brought little good, since it has endangered employment security and disabled the protection of these persons, with a reduced scope of rights, which are not specified in the existing normative framework. Here we primarily mean the right of employees to vocational training and development, as well as collective rights (information, participation, collective bargaining, trade union organization). Having in mind that fact, it is necessary to specify the de lege ferenda of the rights, obligations and responsibilities of persons engaged outside the employment relationship. At the same time, the most frequently concluded contracts, fixedterm contracts (employment) and contracts for temporary and occasional jobs 
(non-employment), are concluded contrary to the essence of these contracts and legal provisions, because they essentially conceal employment for an indefinite period by abusing the application of legal norms.

\section{Gligorić Slađana}

Asistent i saradnik, Pravni fakultet za privredu i pravosuđe u Novom Sadu, Univerzitet Privredna akademija u Novom Sadu, konsultant u Laura konsalting-u, d.o.o., Srbija

\section{Škorić Sanja}

Vanredni profesor, Pravni fakultet za privredu i pravosuđe u Novom Sadu, Univerzitet Privredna akademija u Novom Sadu, Srbija

\section{FLEKSIBILNI OBLICI RADA I RADNOG ANGAŽOVANJA}

REZIME: Globalni trendovi u radnom svetu jasno pokazuju promene u karakteru radnih odnosa sa značajnom zastupljenosti fleksibilnih oblika rada. U pitanju je atipična forma organizovanja rada koja nastaje kao posledica snažnih globalizacijskih tokova, ekomomske krize, informatičke i tehnološke revolucije, a koja stoji nasuprot radnopravnog standarda klasičnog radnog odnosa, što je ugovor o radu na neodređeno vreme sa punim radnim vremenom. Polazeći od koncepta fleksigurnosti, kao dominantnog koncepta u EU, fleksigurnost nastoji uspostaviti balans između fleksibilnosti u oganizaciji rada, a zarad očuvanja stabilnosti. Fleksibilnom organizacijom rada i radnog vremena uspostavlja se svojevrsni balans između radnog vremena, vremena za odmor i vremena za socijalizaciju i društvenu aktivnost. No, sa druge strane fleksibilnom organizacijom rada mogu se umanjiti prava zaposlenih i radno angažovanih, posebno ukoliko se ovakva forma rada zloupotrebljava u praksi ugovorima koji se zaključuju suprotno njihovoj esenciji ili zakonskoj normi. Autori koriste istorijski, uporedno pravni i sociološki metod, kao i statističke podatke u analizi predmeta istraživanja sa ciljem pružanja konkretnih predloga radi unapređenja postojećeg normativnog okvira.

Ključne reči: rad i radni odnosi, fleksibilni oblici rada, fleksibilna organizacija radnog vremena. 


\section{References}

1. International Labour Office (2008). Resolution concerning the measurement of working time, Downloaded 2021, September 01 from https:// www.ilo.org/wcmsp5/groups/public/---dgreports/---stat/documents/normativeinstrument/wcms_112455.pdf

2. International Labour Office (2004).Conditions of Work and Employment Programme. Downloaded 2021, September 01 from https://www.ilo.org/ wcmsp5/groups/public/---ed_protect/---protrav/---travail/documents/publication/wcms_170708.pdf

3. International Labour Office. Hours of Work (Industry) Convention, 1919 (No.1).Downloaded2021,September01 https://www.ilo.org/dyn/normlex/ en/f?p=NORMLEXPUB:12100:0::NO::P12100_ILO_CODE:C001

4. Jašarević, S. (2018). Radno pravo Srbije u XX i XXI veku [Labour law in Serbia in the XX and XXI centuries]. Zbornik Pravnog fakulteta u Novom Sadu, 52 (3), pp. 925-943

5. Jašarević, S. (2015) Nove forme rada u Evropskoj uniji i Srbiji, [New forms of work in European Union and Serbia]. Radno i socijalno pravo, 19 (2), pp. 1-22

6. Jašarević, S. (2012). Fleksibilizacija rada: rešenje ili zabluda rada [Flexible Work: Right Solution or Fallacy]. Zbornik radova Pravnog fakulteta u Novom Sadu, 46 (4), pp. 173-192

7. Kovačević, Lj. (2021). Zasnivanje radnog odnosa [Employment]. Beograd: Pravni fakultet Univerziteta u Beogradu

8. Kovačević, Lj. (2016). Valjani razlozi za otkaz ugovora o radu [Valid reason for termination of employment contract]. Beograd: Pravi fakultet Univerziteta u Beogradu

9. Kovačević, Lj. (2013). Pravna subordinacija u radnom odnosu njene granice [Legal subordination in the employment relationship and its limits reason]. Beograd: Pravni fakultet Univerziteta u Beogradu

10. Kovačević, Lj. (2008). Ugovor o radu sa nepunim radnim vremenom: odnos načela jednakosti i načela srazmernosti [Part time employment contract: the relatioship between the principle of equality and the principle od proportionality]. Radno i socijalno pravo: časopis za teoriju i praksu radnog $i$ socijalnog prava, 12 (1), pp. 224-248

11. Messenger, J. (2018). Working time and the future of work. Geneva: International Labour Office-Geneva

12. Midžović, M. (2020). Radno pravo i fleksibilni oblici rada [Labour law and flexible forms of work] In: Jelović, B. (ed.), Naučno istraživački 
projekat „Pravni aspekti savremenih društvenih kretanja u Republici Srbiji”: tematski zbornik - projekat. Sv. 2 [Scientific research project "Legal aspects of contemporary social movements in the Republic of Serbia:" thematic collection - project, Vol. 2] (pp. 349-362). Kosovska Mitrovica: Univerzitet u Prištini sa privremenim sedištem u Kosovskoj Mitrovici, Pravni fakultet

13. Ostrovidov Jakšić, A. (2017). Postoji li mogućnost primjene koncepta fleksigurnosti na tržište rada u Republici Hrvatskoj? [Is there a possibility to apply the concept of flexicurity in the labor market of the Republic of Crotia?], Privredna kretanja i ekonomska politika, 26 (1 (140)), pp. 43-83

14. Reljanović, M. (2019). Ugovori sa nultim radnim vremenom, [Zero working hours contract ], Strani pravni život, (3), pp. 33-47

15. Trades Union Congress, The future of flexible work, 2021. A TUC report, TUC, Downloaded 2021, August, 11 from https://www.tuc.org.uk/ research-analysis/reports/future-flexible-work?page $=6$ )

16. Urdarević, B. (2020). Radno vreme i fleksibilizacija rada [Working time and flexibilisation of work]. In: Soković, S. (ed.), Usklađivanje pravnog sistema Srbije sa standardima Evropske unije [Harmonization of the legal system of Serbia with the standards of the European Union] (pp. 75-86). Kragujevac: Pravni fakultet, Institut za pravne i društvene nauke

17. Van Eyck, K. (2003). Flexibilization Employment: An Overview. Geneva: International Labour Office

18. Zakon o radu, [Labor Law], Službeni glasnik RS, br. 24/05, 61/05, 54/09, 32/13, 75/14 i 13/17 - odluka US, 113/17 i 95/18-autentično tumačenje

19. Zakon o pojednostavljenom radnom angažovanju na sezonskim poslovima $\mathrm{u}$ određenim delatnostima [Law on Simplified Employment in Seasonal Jobs in Certain Activities]. Službeni glasnik RS, br. 20/18

20. Škorić, S. (2020). Primena digitalne tehnologije kod registracije privrednih subjekata [The application of digital technology in business registration], Pravo, teorija i praksa, 37 (4), pp. 1-12 